\title{
Morphology and immunoreactivity of canine and feline extramedullary plasmacytomas
}

\author{
M. Mikiewicz, I. Otrocka-Domagała, K. Paździor-Czapula, M. Gesek \\ Department of Pathological Anatomy, Faculty of Veterinary Medicine, \\ University of Warmia and Mazury in Olsztyn, Oczapowskiego 13, 10-719 Olsztyn, Poland
}

\begin{abstract}
The aim of the study was the evaluation of morphology and immunophenotype of canine (19 cases) and feline (7 cases) extramedullary plasmacytomas. Tumours, located in skin, oral cavity and spleen were surgically excised, fixed and processed for histopathology and immunohistochemistry (CD79 $\alpha, C D 18$, proliferating cell nuclear antigen, metallothionein). Histologically, tumours were classified into mature, cleaved, asynchronous, polymorphous blastic, hyalin, or monomorphous blastic type. All evaluated tumours showed cytoplasmic expression of $\mathrm{CD} 79 \alpha$ antigen. The expression of CD18 was observed in canine cutaneous and splenic tumours. In canine tumours expression of metallothionein was low to moderate, while in feline plasmacytomas - absent or low. In canine tumours, the mitotic index and proliferating cell nuclear antigen index were positively correlated with the expression of metallothionein. In feline tumours no correlation between mitotic index, proliferating cell nuclear antigen and metallothionein was found. This is the first study describing expression of metallothionein in canine and feline extramedullary plasmacytoma.
\end{abstract}

Key words: plasma cell tumour, metallothionein, dog, cat, immunohistochemistry

\section{Introduction}

According to the classification of the World Health Organization, plasma cell tumour is the neoplasm arising from mature B-cells, producing immunoglobulin (Ig) (Valli et al. 2002). Canine and feline plasma cell tumours can be divided into: multiple myeloma (MM) and solitary plasmacytoma with solitary osseous plasmacytoma and extramedullary plasmacytoma (EMP) subtypes. Cutaneous EMP, together with canine cutaneous histiocytoma, neuroendocrine tumours, transmissible venereal tumour, mast cell tumours, and cutaneous lymphoplasmocytic lymphoma are included in the group of round cell tumours. Due to its nonspecific morphology, EMP is often misdiagnosed, therefore immunohistochemistry is necessary for definitive diagnosis (Morton et al. 1986, Baer et al. 1989, Ramos-Vara et al. 2007). Tumour cells express $\mathrm{CD} 79 \alpha$, a transmembrane protein which is a part of B-cell antigen receptor (BCR). This protein is specific to B lymphocytes and plasma cells (Schrenzel et al. 1998, Ramos-Vara et al. 2007). Due to antibodies production, detection of the lambda chain subunit of immunoglobulin is a useful diagnos-

Correspondence to: M. Mikiewicz, e-mail: mateusz.mikiewicz@uwm.edu.pl 
tic tool (Rowland and Linke 1994, Majzoub et al. 2003). Neoplastic plasma cells can also express CD18 antigen (Ramos-Vara et al. 2007).

EMP is uncommon neoplasm in dogs and cats (Baer et al. 1989, Adelman et al. 2014), and occurs especially in old animals (Rannou et al. 2009). The predisposed locations in dogs are pinnae, digits, and oral cavity (Van Wettere et al. 2009, Gupta et al. 2014). In dogs, malignancy of the neoplasm depends on the primary lesion localization. Cutaneous and oral cavity EMPs have more benign behavior than EMPs localized elsewhere (Borgatti 2010, Gupta et al. 2014). In cats, European Short-Haired breed is predisposed to EMP (Majzoub et al. 2003, Borgatti 2010). EMP in cats mostly arises in the gastrointestinal tract, especially rectal mucosa, sometimes tumour can be found in the esophagus, lungs, spleen, kidney, retroperitoneal space, orbit, and brain (Majzoub et al. 2003, Borgatti 2010). The previous studies revealed that the feline EMPs are mostly benign. However, the possibility of metastases and recurrence cannot be excluded (Platz et al. 1999, Gupta et al. 2014). In contrast to multiple myeloma, there is no bone and bone marrow involvement in animals (Gupta et al. 2014).

Metallothioneins (MTs) are members of a family of cysteine-rich proteins, located in cytoplasm and during $\mathrm{S}$ phase also in the nucleus. Key functions of these proteins are free radicals neutralization, immunomodulation, and apoptosis inhibition. The metal-bound MT shields DNA from damaging agents. The metal-free MT interacts with the tumour suppressor protein $\mathrm{p} 53$, leading to its inactivation, followed by increased cellular proliferation (Dincer et al. 2001, Martano et al. 2012). The studies of MT expression have been limited to canine apocrine gland tumours, mammary gland tumours, melanocytic tumours, and primary pulmonary carcinomas. In cats, reports concerned only melanocytic tumours, mammary gland tumours, and primary pulmonary carcinomas. In canine apocrine gland tumours high MT expression is correlated with malignancy (Martano et al. 2012). However, in dogs the majority of the benign and malignant mammary tumours also express MT. Interestingly, feline benign mammary tumours are mostly MT-negative, and only $30 \%$ of malignant variants of mammary tumours express MT (Dincer et al. 2001).

Proliferating cell nuclear antigen (PCNA) is a subunit of DNA polymerase delta and its main function is the DNA repair. The high PCNA level can be found in replicating cells during the cell cycle's from late G1 phase to early S phase (Webster et al. 2007). Overexpression of PCNA has been correlated with cellular proliferation in malignant tumours, and its higher value is associated with advanced stage of ma- lignancy (Alexandrakis et al. 2005, Tsirakis et al. 2011). In canine mast cell tumours PCNA has been shown to be one of the tumour malignancy indicators (Simoes et al. 1994, Webster et al. 2007). The MT expression is positively correlated with PCNA in human benign and malignant laryngeal epithelial tumours (Ioachim et al. 1999). The correlation of MT and PCNA has not been studied in canine and feline EMPs.

The aims of this study were to compare the morphology of canine and feline EMPs and evaluation of CD79, CD18, MT and PCNA expression by neoplastic cells.

\section{Materials and Methods}

The study included cutaneous, oral cavity and splenic tumours collected from 19 dogs (mongrels $\mathrm{n}=14$, Rottweilers $\mathrm{n}=2$, Golden Retriever $\mathrm{n}=1$, Beagle $\mathrm{n}=1$, Yorkshire Terrier $\mathrm{n}=1$ ) and 7 cats (European Short-Haired $n=7$ ). Detailed data is summarized in Table 1 and Table 2. The tumours were surgically excised, immediately fixed in $10 \%$ neutral formalin, processed routinely and paraffin wax-embedded. Sections were stained with haematoxylin and eosin (H\&E) and toluidine blue (to exclude mast cell tumours). The sections for immunohistochemistry were mounted on silanized glass slides, deparaffinized, rehydrated, and exposed to antigen retrieval. The immunohistochemical examination was performed using primary antibodies, visualization system, and 3, 3'- diamonobenzidine (DAB) as chromogen (Table 3).

The specimens were counterstained with Mayer's haematoxylin. Positive controls for canine and feline tumours separately were processed together with the evaluated slides (CD79 $\alpha$ - tonsil; CD18 - lymph node; MT - mammary gland; PCNA - skin). As negative controls, the primary antibody was replaced with mouse IgG2a (DAKO, Glostrup, Denmark) at the appropriate dilution (MT and PCNA), mouse IgG1 (AbD Serotec, Raleigh, North Carolina, USA) at the appropriate dilution $(\mathrm{CD} 79 \alpha)$ or omitted (CD18). The slides were evaluated in light microscope BX 52 (Olympus, Japan) using Cell^B (Olympus, Japan) software. The brown precipitate in CD79 $\alpha$ and CD18 immunolabelling was regarded as the positive reaction. The PCNA index was expressed as the percentage of PCNA-positive cells in ten randomly chosen areas of the slide (HPF 400x). The mitotic index has been counted in ten randomly-chosen areas of the slide (HPF 400x). Statistical calculations were performed using Statistica software ver 12.0 (Tulsa, OK, USA). Mean value and standard deviation (SD) was 
Table 1. Site of lesion, sex, age, mitoses, and immunohistochemical labeling of tumour cells in 19 dogs with plasma cell tumour.

\begin{tabular}{ccccccccc}
\hline Site & No. Dogs & $\begin{array}{c}\text { Sex } \\
\text { (male/ } \\
\text { female })\end{array}$ & $\begin{array}{c}\text { Mean age } \\
\text { (years } \\
\text { and SD) }\end{array}$ & $\begin{array}{c}\text { Mitoses } \\
\text { (mean } \\
\text { and SD) }\end{array}$ & CD18 & CD79 $\alpha$ & $\begin{array}{c}\text { PCNA } \\
\text { (mean } \\
\text { and SD) }\end{array}$ & $\begin{array}{c}\text { IRS } \\
\text { (MT } \\
\text { expression) }\end{array}$ \\
\hline Skin & 11 & $3 / 8$ & $10.18( \pm 2.47)$ & $12.73 \pm 10.02$ & + & + & $40.73 \pm 13.94$ & $0-6$ \\
\hline Spleen & 5 & $2 / 3$ & $11.4( \pm 3.13)$ & $5.75 \pm 2.5$ & + & + & $25.2 \pm 4.38$ & $1-4$ \\
\hline $\begin{array}{c}\text { Oral } \\
\text { cavity }\end{array}$ & 3 & $1 / 2$ & $11.67( \pm 3.79)$ & $10.67 \pm 6.43$ & - & + & $32.33 \pm 11.37$ & $2-4$ \\
\hline Total & 19 & $6 / 13$ & $10.74( \pm 2.76)$ & $10.83 \pm 8.57$ & & $34.35 \pm 13.21$ & $0-6$ \\
\hline
\end{tabular}

Table 2. Site of lesion, sex, age, mitoses, and immunohistochemical labeling of tumour cells in 7 cats with plasma cell tumour.

\begin{tabular}{ccccccccc}
\hline Site & No. cats & $\begin{array}{c}\text { Sex } \\
\text { (male/ } \\
\text { female) }\end{array}$ & $\begin{array}{c}\text { Mean age } \\
\text { (years } \\
\text { and SD) }\end{array}$ & $\begin{array}{c}\text { Mitoses } \\
\text { (mean } \\
\text { and SD) }\end{array}$ & CD18 & CD79 $\alpha$ & $\begin{array}{c}\text { PCNA } \\
\text { (mean } \\
\text { and SD) }\end{array}$ & $\begin{array}{c}\text { IRS } \\
\text { (MT } \\
\text { expression) }\end{array}$ \\
\hline Skin & 3 & $2 / 1$ & $7.17( \pm 5.30)$ & $11.33 \pm 4.16$ & ND $^{*}$ & + & $28.67 \pm 7.37$ & $0-2$ \\
\hline Spleen & 1 & $0 / 1$ & 13 & 5 & ND $^{*}$ & + & 20 & 2 \\
\hline $\begin{array}{c}\text { Oral } \\
\text { cavity }\end{array}$ & 3 & $1 / 2$ & $8.67( \pm 4.04)$ & $6.33 \pm 2.08$ & ND $^{*}$ & + & $24.67 \pm 4.93$ & 0 \\
\hline Total & 7 & $3 / 4$ & $8.64( \pm 4.64)$ & $8.29 \pm 3.95$ & & & $25.71 \pm 6.05$ & $0-2$ \\
\hline
\end{tabular}

*ND - not done

Table 3. Primary antibodies used with the particular methods of antigen retrieval and visualization.

\begin{tabular}{|c|c|c|c|c|c|}
\hline $\begin{array}{l}\text { Primary } \\
\text { antibody }\end{array}$ & Clone & Dilution & Source & $\begin{array}{l}\text { Antigen } \\
\text { retrival }\end{array}$ & Visualization system \\
\hline $\mathrm{CD} 79 \alpha$ & $\begin{array}{l}\text { Monoclonal mouse anti- } \\
\text {-human MCA2538 }\end{array}$ & $1: 100$ & $\begin{array}{c}\text { AbD Serotec, } \\
\text { USA }\end{array}$ & $\begin{array}{c}4 \times 5 \mathrm{~min} * \\
\text { TrisEDTA } \\
\text { buffer } \mathrm{pH}=9\end{array}$ & $\begin{array}{c}\text { EnVision }+ \text { System-HRP } \\
\text { Mouse }(\mathrm{DAB})^{* *}\end{array}$ \\
\hline CD18 & $\begin{array}{l}\text { Monoclonal mouse anti- } \\
\text {-canine CA16.3C10 }\end{array}$ & $1: 10$ & $\begin{array}{l}\text { P.F. Moore, } \\
\text { USA }\end{array}$ & $\begin{array}{c}\text { Proteinase } \\
\text { K Ready-to-Use } \\
5 \text { min, DAKO, } \\
\text { Denmark }\end{array}$ & $\begin{array}{l}\text { EnVision }+ \text { System-HRP, } \\
\text { Mouse }(\mathrm{DAB})^{* *}\end{array}$ \\
\hline Metallothionein & $\begin{array}{c}\text { Monoclonal mouse anti- } \\
\text {-metallothionein clone } \\
\text { E9 }\end{array}$ & $1: 50$ & $\begin{array}{l}\text { DAKO, } \\
\text { Denmark }\end{array}$ & $\begin{array}{c}2 \times 5 \text { min* } \\
\text { TrisEDTA } \\
\text { buffer } \\
\text { pH }=9\end{array}$ & $\begin{array}{c}\text { EnVision }+ \text { System-HRP } \\
\text { Mouse }(\mathrm{DAB})^{* *}\end{array}$ \\
\hline PCNA & $\begin{array}{l}\text { Monoclonal mouse anti- } \\
\text {-proliferating cell nuclear } \\
\text { antigen clone PC10 }\end{array}$ & $1: 200$ & $\begin{array}{l}\text { DAKO, } \\
\text { Denmark }\end{array}$ & $\begin{array}{c}2 \times 5 \mathrm{~min}^{*} \\
\text { TrisEDTA } \\
\text { buffer } \mathrm{pH}=9\end{array}$ & $\begin{array}{c}\text { EnVision }+ \text { System-HRP } \\
\text { Mouse }(\mathrm{DAB})^{* *}\end{array}$ \\
\hline
\end{tabular}

* antigen retrieval was conducted in a microwave oven, 650Watts.

** Dako, Glostrup, Denmark.

calculated for the mitotic and PCNA index. In order to evaluate the expression of MT a semi-quantitative scale of ImmunoReactive Score (IRS) was applied, in which intensity of colour reaction and positive cells percentage were taken into account (Remmele and
Stegner, 1987). Relationships between mitotic index, IRS, and PCNA index were evaluated using the Spearman rank correlation analysis ( $\mathrm{r}$ : Spearman rank correlation coefficient). The correlations were considered statistically significant when $\mathrm{p}<0.05$. 

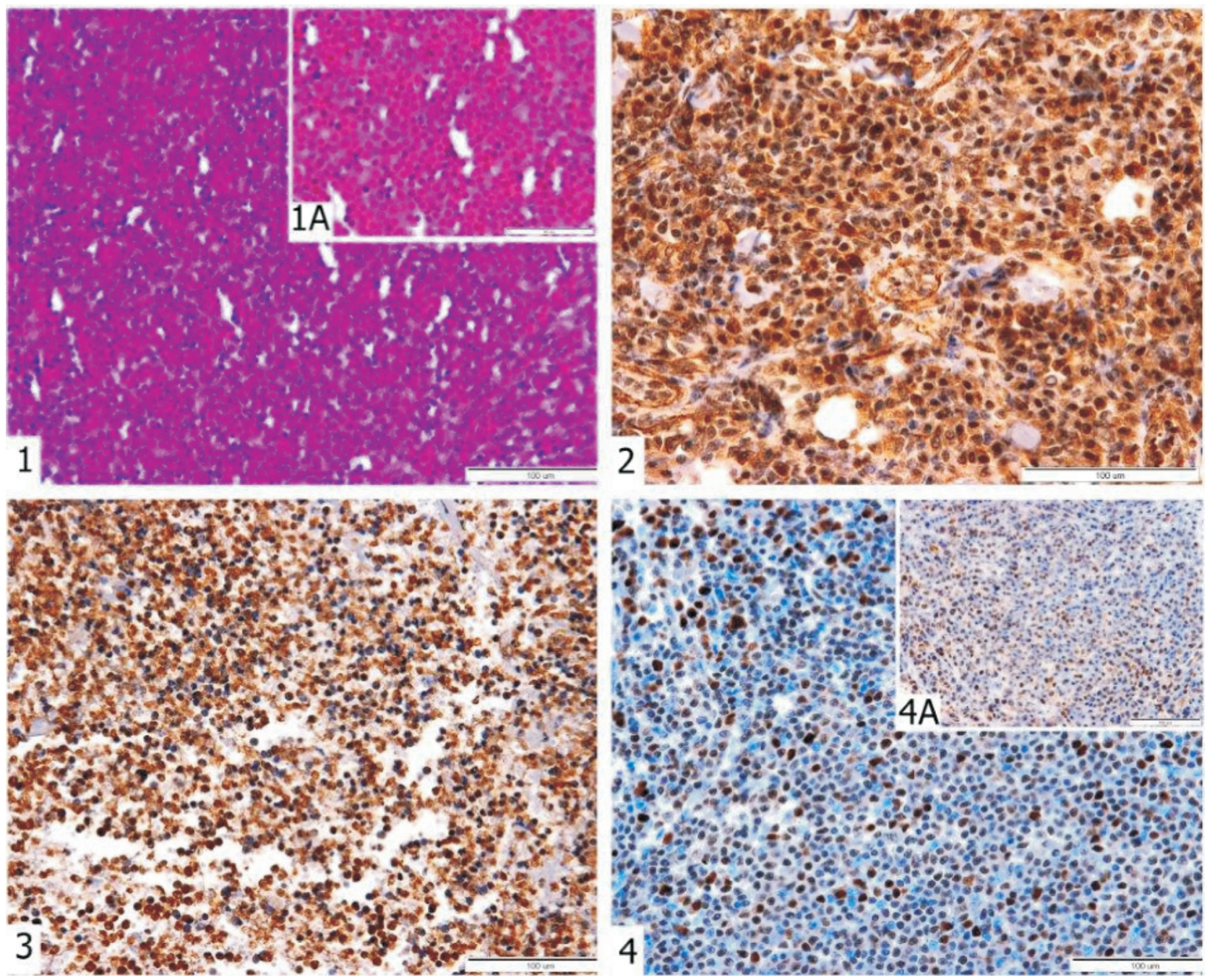

Fig. 1. EMP mature type, spleen. Dog. Round to oval cells with round to oval, eccentrically located nuclei are present. HE. Fig. 1A EMP mature type, spleen. Dog. Magnification x100. HE; Fig. 2. EMP mature type, spleen. Dog. Immunohistochemical labelling to CD79 $\alpha$. CD79 $\alpha$ immunolabelling, DAB; Fig. 3. EMP mature type, spleen. Dog. Immunohistochemical labelling to CD18. CD18 immunolabelling, DAB; Fig. 4. EMP mature type, spleen. Dog. A large percentage of the tumour cell nucleus showed PCNA expression. PCNA immunolabelling, DAB. Fig. 4A. EMP monomorphous blastic type, skin. Dog. Low number of tumour cells are MT positive. MT immunolabelling, DAB.

\section{Results}

The evaluated tumours represented mature type (canine $n=4$; feline $n=2$ ), cleaved type (canine $n=3$, feline $n=2$ ), asynchronous type (canine $n=2$, feline $\mathrm{n}=2$ ), polymorphous blastic type (canine $\mathrm{n}=4$; feline $n=1$ ), monomorphous blastic type (canine $n=5$ ) and hyaline type (canine $\mathrm{n}=1$ ).

In the mature type (Fig. 1), the tumour cells were round to oval with minimal anisocytosis and anisokaryosis, eccentrically located nuclei and clumped chromatin („,cartwheel”), resembling mature plasma cells (Fig 1A). In canine and feline tumours mitotic figures ranged from 3 to 7 per 10/HPFx400. Occasionally, multinucleated giant cells were seen.

In the cleaved type, the prominent feature of the tumour cells was convoluted nuclei and slightly eosinophilic cytoplasm. The cells had indistinct cell borders. The chromatin was finely granulated and nucleoli were invisible. In canine and feline tumours mitotic figures ranged from 4 to 18 per 10/HPFx 400 . Fibrous septa divided tumour cells into packets. The multinucleated giant cells were present.

In the asynchronous type (Fig. 5), blastic cells with eccentric nucleus and centrally located nucleolus were seen. Abundant, basophilic cytoplasm with perinuclear halo was observed (Fig. 5A). In canine and feline tumours mitotic figures ranged from 5 to 10 per 10/HPFx400. Alike in cleaved type the giant cells were numerous.

In the polymorphous blastic type, the tumour cells showed marked anisocytosis, anisokaryosis and poly- 

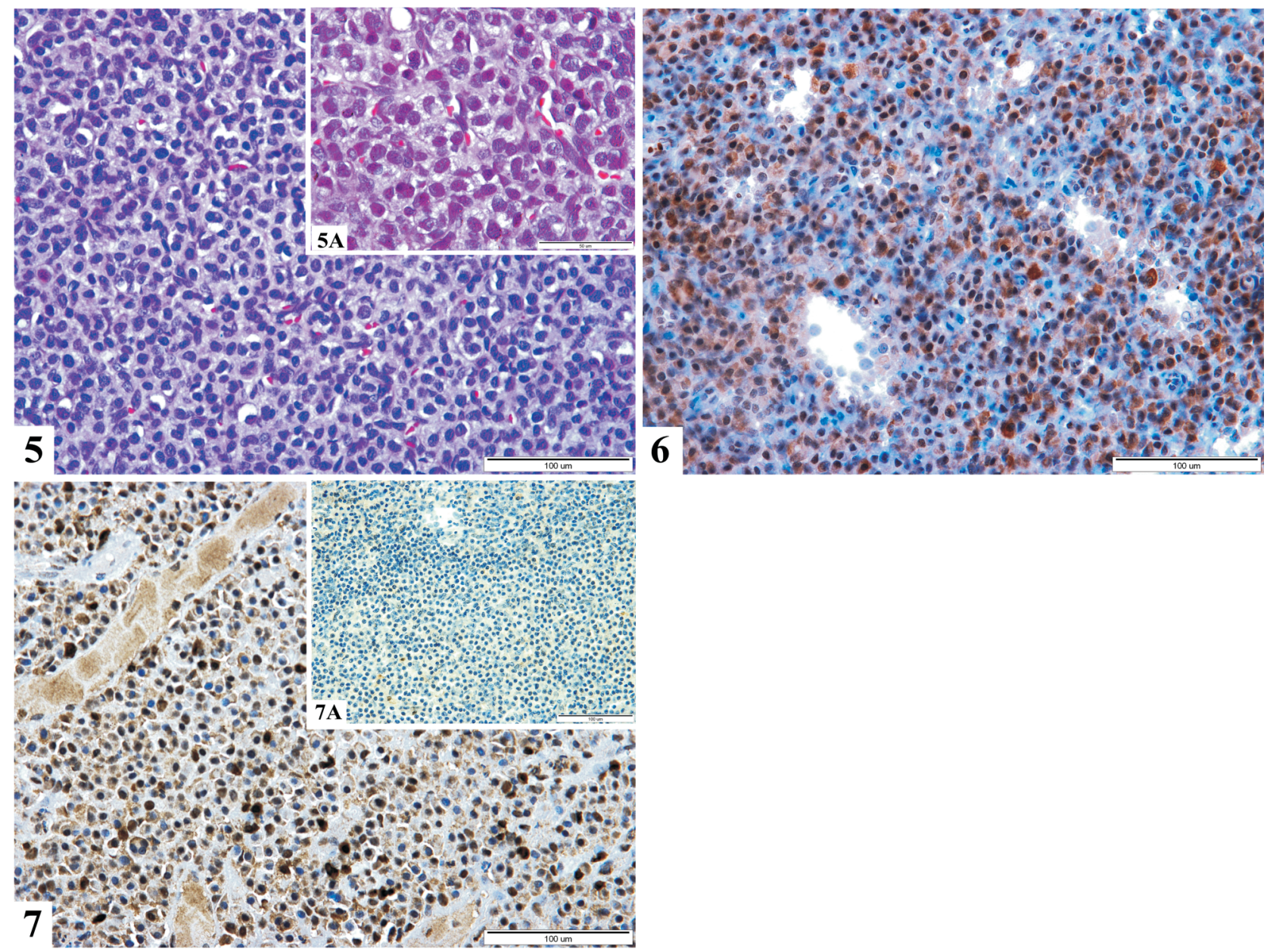

Fig. 5. EMP, asynchronous type, skin. Cat. Round to oval cells with round to oval, eccentrically located nuclei and clumped chromatin are present. HE. Fig. 5A EMP asynchronous type, skin. Cat. Magnification x100. HE; Fig. 6. EMP, asynchronous type, skin. Cat. Immunohistochemical labelling to CD79 $\alpha$. CD79 $\alpha$ immunolabelling, DAB; Fig. 7. EMP, asynchronous type, skin. Cat. A large percentage of the tumour cell nucleus showed PCNA expression. PCNA immunolabelling, DAB. Fig. 7A. EMP polymorphous blastic type, skin. Cat. Most tumour cells are MT negative. MT immunolabelling, DAB.

morphism. The blastic cells were admixed with mature cells. In canine tumours mitotic figures ranged from 12 to 35 per 10/HPFx 400 , while in feline there was 16 per 10/HPFx400. The multinucleated giant cells were common. Some giant cells had up to 7 nuclei.

In the monomorphous blastic type, the cellular population was monotonous. The tumour cells were round to oval, similar in size, with light, vast nucleus and small 1 to 3 nucleoli per cell. In canine tumours mitotic figures ranged from 6 to 10 per 10/HPFx 400 .

In the hyaline type, the distinguishing feature of the tumour cells was abundant cytoplasm, crescent-shaped, eccentrically located nuclei, and central prominent 1 to 5 nucleoli per cell. The number of mitotic figures was 9 per 10/HPFx400. A few giant cells were seen in the tumour.

Despite of EMP type the mitotic index ranged depending on the tumour localization in both dogs and cats. In dogs, mitotic figures counted per 10/HPFx400 numbered from 5 to 35 in skin, 3 to 9 in spleen, and 6 to 18 in oral cavity EMPs (Table 1). In the skin asynchronous $(\mathrm{n}=2)$, polymorphous blastic $(\mathrm{n}=4)$, and monomorphous blastic $(\mathrm{n}=5)$ types were observed. In the spleen mature $(n=4)$ and hyaline $(n=1)$ types were observed. In the oral cavity only cleaved $(n=3)$ type was found. In cats, mitotic figures counted per 10/HPFx400 numbered from 8 to 16 in skin, 5 in spleen, and 4 to 8 in oral cavity EMPs (Table 2). In the skin asynchronous $(\mathrm{n}=2)$ and polymorphous blastic $(n=1)$ types were observed. In the spleen and oral cavity mature type $(n=2)$ was seen. Cleaved type $(\mathrm{n}=2)$ was only diagnosed in oral cavity.

In dogs (Fig. 2) and cats (Fig. 6) EMP cells had high, positive $(90 \%)$ cytoplasmic expression of CD79 $\alpha$. In dogs, approximately $80 \%$ of the neoplastic cells showed high, cytoplasmic CD18 expression in cutaneous and splenic (Fig. 3) tumours, however in oral cavity tumours the expression of $\mathrm{CD} 18$ was 


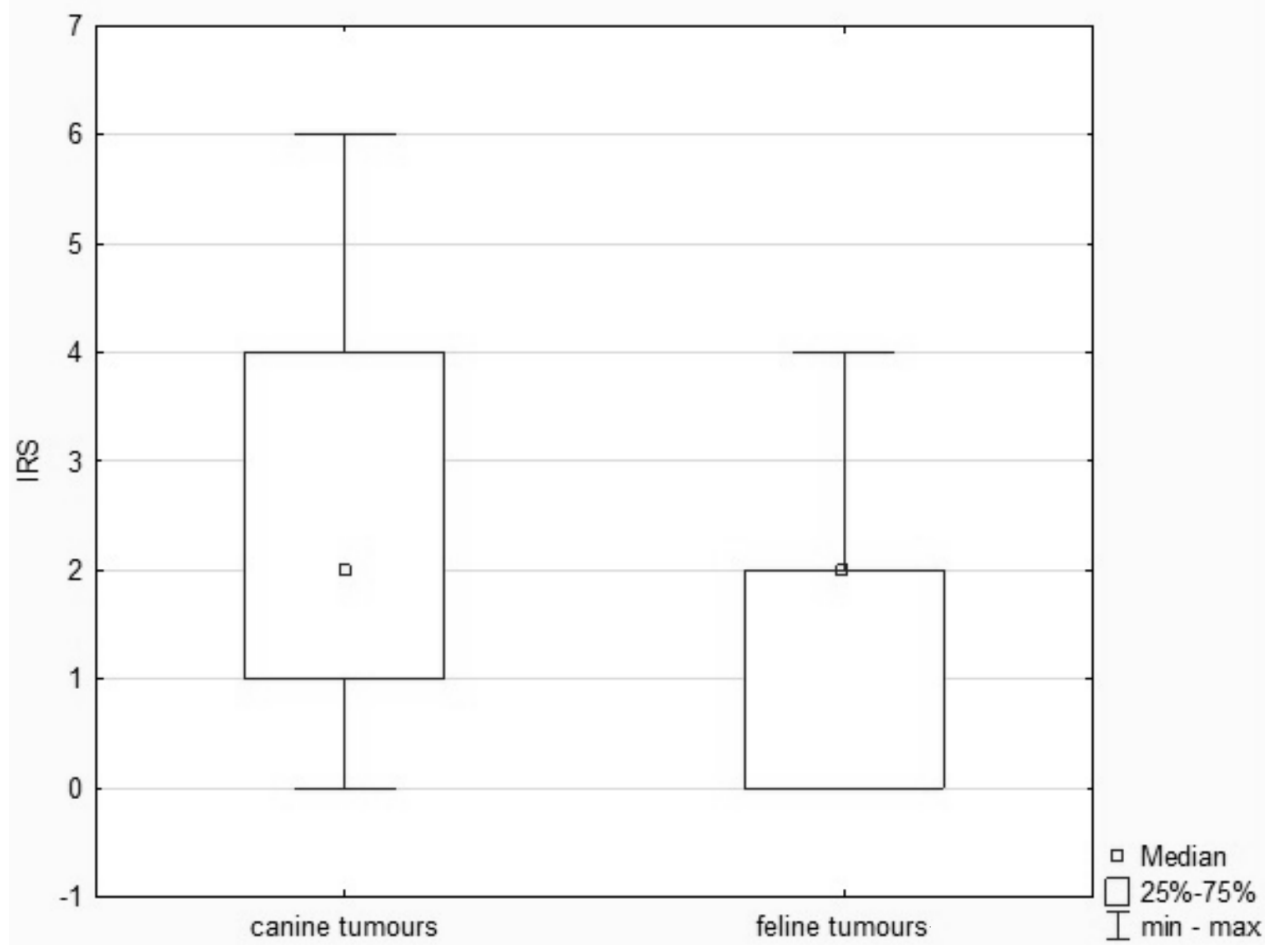

Fig. 6. IRS in canine $(n=19)$ and feline tumours $(n=7)$.

absent. The lack of CD18 immunolabelling in the feline positive control slide indicates, that anti-canine antibody used in this study does not cross-react with the feline antigens. The PCNA expression in both canine (Fig. 4) and feline (Fig. 5) tumours varied, but the mean value was approximately $30 \%$. In dog and cat tumours MT expression was variable. Most of canine tumour types had low MT expression (Fig. 4A), however only one cutaneous polymorphous blastic (thoracic area) EMP type had moderate MT expression. Other cutaneous polymorphous blastic type had low MT expression. One of the asynchronous type (skin, axillary area) showed no MT expression, but the other one from skin of the hind limb had low expression. In cats low MT expression (Fig. 7A) was observed in polymorphous blastic (skin) and mature type (spleen). In asynchronous (skin), cleaved and mature type (spleen and oral cavity) absent MT expression was seen. Detailed characteristics of the immunoreactivity of evaluated tumours were collected in Table 1 and Table 2.

The results of IRS are shown on Fig. 6. In canine tumours, the mitotic index $(\mathrm{r}=0.805 ; \mathrm{P}=0.000)$ and PCNA index $(\mathrm{r}=0.53 ; \mathrm{P}=0.019)$ were positively correlated with IRS. In feline tumours, there was no correlation between the mitotic index and IRS $(r=0.642$; $\mathrm{P}=0.120)$, and PCNA index and IRS $(\mathrm{r}=0.531$; $\mathrm{P}=0.618$ ).

\section{Discussion}

Plasma cell tumours are neoplasms arising from B-lymphocytes, which occur in mature animals and are more frequently seen in dogs aged 11 years or more, and cats aged 9 years or more. The evaluated in our study EMPs were seen mostly in older animals, what corresponds to other reports (Platz et al. 1999, Majzoub et al. 2003, Rannou B et al. 2009, Gupta et al. 2014). Most of the tumours were located in the skin, what was also revealed by other authors (Platz et al. 1999). The vast majority of the evaluated canine EMPs occurred in mongrels. The previous studies revealed that American Cocker Spaniel, English Cocker Spaniel, Airdale Terrier, Kerry Blue Terrier, Scottish Terrier, Yorkshire Terrier, Golden Retriever, Labrador Retriever and mixed breeds are predisposed to EMP (Cangul et al. 2002, Gupta et al. 2014). The evaluated canine EMPs were seen more often in bitches than in males, in contrary to previous studies (Brunnert and Altman 1991, Cangul et al. 2002).

In the present study, in cats EMP affected only the European Short-Haired breed, equally females and males. Although, there are single records of EMP in Abyssinian, Long-Haired Persian and Burmese cats, the breed predisposition of EMP in cats is unknown. Male cats seem to be most affected (Majzoub et al. 2003). The low number of feline EMPs evalu- 
qated in our study do not permit any generalization regarding the breed or sex predispositions.

Regarding morphology of the tumour cells and the tumour architecture, the EMP can be classified into six types (mature, hyalin, cleaved, asynchronous, monomorphous blastic, polymorphous blastic types) (Cangul et al. 2002). The present study described all six types of EMP in dogs, and among them monomorphous blastic type was the most frequent. According to the previous studies, the monomorphous blastic and cleaved type are the most common types of EMPs in dogs (Platz et al. 1999, Cangul et al. 2002).

Due to the similar morphology and tumour architecture, as observed in canine EMP, the same histological types can be distinguished in cats. In a previous study, the asynchronous EMP was the most common type of feline EMP (Majzoub et al. 2003). In our study four types (mature, cleaved, asynchronous, and polymorphous blastic) of EMPs were equally represented, while the monomorphous blastic type and hyaline type were not revealed, what may suggest that these EMP types are rare in cats, however, further study involving more cases of feline EMP should be perform to confirm these findings.

In multiple myeloma, well-differentiated, mature and small cells are indicators of a low grade, whereas plasmablastic, immature cells are the feature of high-grade malignancy tumours. In EMPs, there is no correlation between tumour type and prognosis, however well-differentiated forms appear to have benign behaviour but anaplastic types are considered as locally-aggressive, slowly-progressive and rarely metastasizing tumours (Cangul et al. 2002). The obtained results provided the basis for indicating an increased risk of local recurrence or distant metastases. The follow-up data, not available in the present study, would be necessary to estimate the biological behavior of the evaluated tumours.

Positive CD79 $\alpha$ labelling was observed in all evaluated canine and feline tumours, what was also confirmed in other research (Webb et al. 2008, Van Wettere et al. 2009). However, Moore et al. revealed, that about $20 \%$ of EMPs are CD79 $\alpha$-negative (Moore et al. 2000). CD18 is a marker of all leukocytes, however, its expression is 10 times higher in macrophages, monocytes and dendric cells compared with lymphocytes, as well as plasma cells (Mazzone and Ricevuti 1995, Schrenzel et al. 1998). The expression of CD18 in canine EMP is variable regardless of the tumour type and localization (Ramos-Vara et al. 2007). In our study CD18 expression was observed in cutaneous and splenic tumours, with no immunoreactivity in EMPs located in oral cavity. Nevertheless, the low number of evaluated tumours does not allow to draw any relationship between the tumour localisation and the expression of CD18.

In both canine and feline EMPs, the PCNA and mitotic index was higher in cutaneous and oral cavity tumours than in spleen. This result may indicate that those tumours had more dynamic cellular proliferation, therefore showed more intensive and faster growth.

The positive correlation between MT expression and mitotic index was shown in canine apocrine gland tumours and canine and feline melanomas (Martano et al. 2012). The expression of MT fluctuates during tumour growth, and in some human tumours (breast, colon, kidney, liver, lung, nasopharynx, ovary, prostate, salivary gland, testes, thyroid, and urinary bladder tumours) the level of MT is positively correlated with the proliferation rate and the malignancy grade (Gumulec et al. 2014). On the other hand, a complete lack of MT expression was observed in some human colo-rectal adenocarcinomas, what was linked to spontaneous and mutagenic DNA damage (Dincer et al. 2001). In the evaluated canine EMPs, the expression of MT was variable, but usually low to moderate, in contrast to the feline EMPs, where MT expression was absent or low despite the type and tumour localization. The positive correlation between PCNA, mitotic index and IRS in canine tumours suggests, that the expression of MT is connected with the tumour growth. However, the mechanism of such relationship remains unclear. In the human cervical carcinoma, the expression of MT increased with the intensity of the local spread of the disease (Walentowicz-Sadlecka et al. 2013). In cats, the tumour growth is probably unrelated to the expression of MT, as there is no correlation between PCNA, mitotic index and IRS. However, the study including more cases of the feline EMPs is necessary to confirm the lack of the relationship between expression of MT and tumour growth.

Summarizing, mature, cleaved, asynchronous, and polymorphous blastic histological types of EMPs can be diagnosed in both dogs and cats. Additionally, in dogs monomorphous blastic and hyaline types could be observed. The absence of the two former types of EMPs in cats can indicate that those types have rare occurrence in these animals. CD79 $\alpha$ seems to be a good diagnostic marker for EMPs in dogs and cats. In canine tumours positive correlation between PCNA, mitotic index and IRS is mostly connected with tumour growth, however, in cats no such correlation was found, still the study including more cases of feline EMPs is necessary to confirm the occurrence of monomorphous blastic, hyaline type and the absence of the relationship between expression of MT and tumour growth. 


\section{References}

Adelman L, Larson V, Sissener T, Sportswood T (2014) Extramedullary plasmacytoma in the lung of a Doberman pinscher dog. Can Vet J 55: 1237-1240.

Alexandrakis MG, Passam FH, Dambaki K, Passam AM, Nalbanti F, Stathopoulos ES, Kyriakou DS (2005) The assessment of proliferating cell nuclear antigen immunostaining in myelodysplastic syndromes and its prognostic significance. Eur J Histochem 49: 27-32.

Baer KE, Patnaik AK, Gilbertson SR, Hurvitz AI (1989) Cutaneous plasmacytomas in dogs: a morphologic and immunohistochemical study. Vet Pathol 26: 216-221.

Borgatti A (2010) Plasma cell tumors. In: Weiss DJ, Wardrop KJ (eds) Schalm's veterinary hematology. Blackwell Publishing Ltd, USA, pp 516-518.

Brunnert SR, Altman NH (1991) Identification of immunoglobulin light chains in canine extramedullary plasmacytomas by thioflavine $\mathrm{T}$ and immunohistochemistry. J Vet Diagn Invest 3: 245-251.

Cangul IT, Wijnen M, Van Garderen E, van den Ingh TS (2002) Clinico-pathological aspects of canine cutaneous and mucocutaneous plasmacytomas. J Vet Med A Physiol Pathol Clin Med 49: 307-312.

Dincer Z, Jasani B, Haywood S, Mullins JE, Fuentealba IC (2001) Metallothionein expression in canine and feline mammary and melanotic tumours. J Comp Pathol 125: $130-136$.

Gumulec J, Raudenska M, Adam V, Kizek R, Masarik $M$ (2014) Metallothionein - immunohistochemical cancer biomarker: a meta-analysis PLoS One 9: e85346.

Gupta A, Fry JL, Meindel M, Gumber S (2014) Pathology in practice. Cutaneous extramedullary solitary digital plasmacytoma in a dog. J Am Vet Med Assoc 244: 163-165.

Ioachim E, Assimakopoulos D, Peschos D, Zissi A, Skevas A, Agnantis NJ (1999) Immunohistochemical expression of metallothionein in benign premalignant and malignant epithelium of the larynx: correlation with p53 and proliferative cell nuclear antigen. Pathol Res Pract 195: 809-814.

Majzoub M, Breuer W, Platz SJ, Linke RP, Hermanns W (2003) Histopathologic and immunophenotypic characterization of extramedullary plasmacytomas in nine cats. Vet Pathol 40: 249-253.

Mazzone A, Ricevuti G (1995) Leukocyte CD11/CD18 integrins: biological and clinical relevance. Haematologica 80: 161-175.

Moore PF, Affolter VK, Vernau W (2000) Immunophenotyping in the dog. In: Bonagura JD (ed) Kirk's current veterinary therapy XIII: Small Animal Practice. WB Saunders Company, USA, pp 505-509.

Martano M, Carella F, Squillacioti C, Restucci B, Mazzotta M, Lo Muzio L, Maiolino P (2012) Metallothionein expression in canine cutaneous apocrine gland tumors. Anticancer Res 32: 747-752.
Morton LD, Barton CL, Elissalde GS, Wilson SR (1986) Oral extramedullary plasmacytomas in two dogs. Vet Pathol 23: 637-639.

Platz SJ, Breuer W, Pfleghaar S, Minkus G, Hermanns W (1999) Prognostic value of histopathological grading in canine extramedullary plasmacytomas. Vet Pathol 36: 23-27.

Ramos-Vara JA, Miller MA, Valli VE (2007) Immunohistochemical detection of multiple myeloma 1 /interferon regulatory factor 4 (MUM1/IRF-4) in canine plasmacytoma: comparison with CD79a and CD20. Vet Pathol 44: 875-884.

Rannou B, Hélie P, Bédard C (2009) Rectal plasmacytoma with intracellular hemosiderin in a dog. Vet Pathol 46: 1181-1184.

Remmele W, Stegner HE (1987) Recommendation for uniform definition of an immunoreactive score (IRS) for immunohistochemical estrogen receptor detection (ER-ICA) in breast cancer tissue. Pathologe 8: 138-140.

Rowland PH, Linke RP (1994) Immunohistochemical characterization of lambda light-chain-derived amyloid in one feline and five canine plasma cell tumors. Vet Pathol 31: 390-393.

Schrenzel MD, Naydan DK, Moore PF (1998) Leukocyte differentiation antigens in canine cutaneous and oral plasmacytomas. Vet Dermatol 9: 33-41.

Simoes JP, Schoning P, Butine M (1994) Prognosis of canine mast cell tumors: a comparison of three methods. Vet Pathol 31: 637-647.

Tsirakis G, Pappa CA, Kaparou M, Katsomitrou V, Hatzivasili A, Alegakis T, Xekalou A, Stathopoulos EN, Alexandrakis MG (2011) Assessment of proliferating cell nuclear antigen and its relationship with proinflammatory cytokines and parameters of disease activity in multiple myeloma patients. Eur J Histochem 55: e21.

Valli VE, Jacobs RM, Parodi AL, Vernau W, Moore PF (2002) Histological classification of hematopoietic tumors of domestic animals, $2^{\text {nd }}$ ed., American Registry of Pathology, Washington, DC, USA.

Van Wettere AJ, Linder KE, Suter SE, Olby NJ (2009) Solitary intracerebral plasmacytoma in a dog: microscopic, immunohistochemical, and molecular features. Vet Pathol 46: 949-951.

Walentowicz-Sadlecka M, Koper A, Galazka K, Koper K, Basta P, Mach P, Skret-Magierlo J, Dutsch-Wicherek M, Sikora J, Grabiec M, Kazmierczak W, Wicherek L (2013) The analysis of metallothionein immunoreactivity in stromal fibroblasts and macrophages in cases of uterine cervical carcinoma with respect to both the local and distant spread of the disease. Am J Reprod Immunol 70: 253-261.

Webb J, Chary P, Northrup N, Almy F (2008) Erythrophagocytic multiple myeloma in a cat. Vet Clin Pathol 37: 302-307.

Webster JD, Yuzbasiyan-Gurkan V, Miller RA, Kaneene JB, Kiupel M (2007) Cellular proliferation in canine cutaneous mast cell tumors: associations with c-KIT and its role in prognostication. Vet Pathol 44: 298-308. 